\title{
УДК373.3.016:004
}

Імбер Вікторія Іванівна

кандидат педагогічних наук,старший викладач

Вінницький державний педагогічний університет імені Михайла Коцюбинського, м. Вінниця, Україна ORCID ID 0000-0003-2908-9654

imbervika@gmail.com

\section{ОРГАНІЗАЦІЯ НАВЧАЛЬНОЇ ВЗАСМОДІЇ ВИКЛАДАЧА І СТУДЕНТІВ ЗАСОБАМИ SMART BOARD}

\begin{abstract}
Анотація. У статті розглядаються етапи організації навчальної взаємодії викладача і студентів засобами Smart Board. Описано можливості оновленого пакета програмного забезпечення SMART Learning Suite, зокрема інтерактивний додаток Smart Lab для організації навчання за ігровими технологіями, новий інструмент оцінювання навчальних досягнень студентів Smart Response 2, організацію співпраці студентів у межах єдиного віртуального робочого простору Smart Amp, роботу студентів на будь-яких персональних пристроях, виконання завдань у режимі online з використанням Smart Learning Suite Online. Визначено, що нові форми організації навчальної взаємодії викладача і студентів можуть бути успішно реалізовані в сучасній системі освіти. Це забезпечить можливість для викладачів створювати інтерактивні заняття, вивільняти час для оцінювання навчальних досягнень студентів, опановувати нові форми організації занять у режимі online, забезпечувати навчання студентів у їхньому власному темпі. Наведено приклади інтерактивних вправ і способи організації навчальної діяльності студентів із залученням інструментів Smart Lab.
\end{abstract}

Ключові слова: навчальна взаємодія викладача i студентів; інтерактивна дошка; віртуальний робочий простір; пакет SMART Learning Suite.

\section{1. ВСТУП}

Постановка проблеми. На сучасному етапі європеїзація освітньої системи в Україні вимагає нових підходів до організації навчальної взаємодії викладача i студентів, забезпечення індивідуально-орієнтованого навчання, розвиток у студентів інтересу і підвищення мотивації до навчання, запровадження кооперації і конкуренції в навчанні, виявлення і розвиток творчих здібностей студентів, створення інтерактивного простору на основі діалогу засобами інформаційно-комунікаційних технологій. Одним iз таких засобів забезпечення інтерактивної взаємодії викладача i студентів $\epsilon$ мультимедійна дошка.

Аналіз останніх досліджень i публікацій. Теоретико-практичні основи організації педагогічного процесу з використанням нових інформаційних технологій, мультимедійних засобів навчання привертали увагу багатьох науковців і практиків. Зокрема, питання організації комп'ютерної комунікації в навчальному процесі, розвиток інформаційної культури педагога, перспективи використання мультимедійних засобів навчання розглядають В. Биков, Р. Гуревич, А. Гуржій, К. Елшир, М. Жалдак, Ю. Жук, Г. Кєдровіч, Г. Козлакова, А. Коломієць, Н.Морзе, І. Підласий, С. Полат, I. Роберт, О. Співаковський та ін. Нові форми представлення навчального матеріалу засобами Smart Board описували Л. Веселовська, I. Кисла, I. Кретова, Н. Уланова, T. Щепакіна та ін. Питання забезпечення сфери освіти теорією i практикою використання інтерактивної дошки порушували Б. Андерсен, Л. Карташова, В. Лапінський, Т. Носенко, В. Осадчий, Н. Решетнікова та ін. У своїх працях вони доводять іiі ефективність як найкращого із сучасних технічних засобів для наочного 
навчання, що існують нині. Зокрема, В. Осадчий у своєму посібнику надає методичну допомогу викладачам щодо використання інструментів i планування занять із застосуванням інтерактивної дошки, описує контроль за тим, що бачить аудиторія й особливості такої ситуації [1]. О. Буйницька, описуючи сучасні інформаційні технології, зазначає, що вчитель, студент, доповідач засобами Smart Board може створити і продемонструвати свою презентацію за зручним сценарієм, зберегти у вигляді альбому з графічними файлами, зафіксувати окремі етапи доповіді й за потреби відтворити їх, робити в процесі доповіді нотатки на слайдах, записувати процес подання інформації i т. ін. Результати широкого застосування програмнотехнологічного навчального комплексу Smart Board вона вбачає у: розвитку інформаційної культури людини; розвитку змісту, методів і засобів навчання до рівня світових стандартів; скороченні терміну та підвищенні якості навчання і тренування на всіх рівнях підготовки кадрів [2, с. 26]. Т. Носенко у своїй праці визначила функції технології Smart Board у структурі заняття: повідомлення нової інформації, ілюстрація, узагальнення, систематизація, навчальний проект, закріплення, контроль. Також вона наголошує на тому, що перевагою використання програмного забезпечення Smart Board i програми Smart Notebook є те, що під час заняття вчитель може легко перебудувати сам процес викладення матеріалу залежно від обставин, вносити корективи, додаткові коментарі, ілюстрації і т. ін. [3].

Ю. Мельничук наголошує, що на занятті 3 мультимедійною підтримкою збільшується його проблемно-пошуковий характер, істотно змінюється роль викладача, який виступає передусім організатором, координатором пізнавальної діяльності студентів. Використання необхідного програмного забезпечення і ресурсів у поєднанні 3 інтерактивною дошкою може поліпшити розуміння навчальних ідей, оскільки інтерактивна дошка допомагає унаочнити складні процеси аналізу, синтезу, порівняння [4].

Теоретичні і методичні праці науковців щодо можливостей використання мультимедійної дошки у навчальному процесі розкривають шляхи ефективної організації заняття у вищому навчальному закладі з іiі допомогою, проте проблема активізації навчання і залучення студентів до розв'язання поставлених завдань у режимі online засобами мультимедійної дошки ще не знайшла відповідного відображення у дослідженнях.

Мета статті - показати можливості використання Smart Board на різних етапах проведення заняття за технологією організації навчальної взаємодії викладача i студентів.

\section{2. РЕЗУЛЬТАТИ ДОСЛІДЖЕННЯ}

Інтенсивний розвиток інформаційно-комунікаційних технологій змінив можливості роботи 3 інформацією. Освоєння нових інформаційних технологій навчання породжує комп'ютерну грамотність. Вона має стати компонентом культури педагога, оскільки розглядається нині як необхідний елемент освіти будь-якого фахівця.

Найбільш сучасним напрямом нових інформаційних технологій навчання, який тепер прогресивно розвивається, охоплюючи різні сфери, є технологія мультимедіа. Вона інтегрує різні види інформації: текст, графіку, мовлення, музику, відеофрагменти, анімацію в єдине мультимедійно-навчальне середовище.

Однією з передумов успішного навчання $є$ дотримання дидактичних принципів, які перебувають у тісному зв'язку 3 формами i методами навчання. Ще Я.А. Коменський одним 3-поміж найважливіших дидактичних принципів вважав 
наочність у навчанні. Він сформулював «золоте правило» дидактики: «... все, що тільки можна, подавати для сприймання відчуттями, а саме: видиме - для сприймання зором, чутне - слухом, запахи - нюхом, смакове - смаком, доступне дотику - через дотик. Якщо якісь предмети одразу можна сприймати кількома відчуттями, нехай вони одразу охоплюються кількома відчуттями...». Цей принцип значною мірою відповідає технології мультимедіа. Адже мультимедіа в дослівному перекладі означає «багатосередовищність», тобто дає можливість одночасно сприймати різного роду інформацію (графічну, відео та звукову, текстову, анімаційну, мультиплікаційну і т. ін.) [5, c. 249].

Одним із таких сучасних засобів навчального призначення $є$ мультимедійна дошка - універсальний технічний засіб візуальної комунікації і навчання, у якому поєднуються характеристики звичайної дошки і новітніх комп'ютерних технологій. Для формування математичної компетенції майбутніх фахівців дошкільної освіти ми використовуємо дошку Smart Board. Вона поєднує в собі потужне програмне забезпечення Smart Notebook і прості управлінські функції [5, с. 249 ].

Психологічні аспекти використання Interactive white board у навчанні дітей 3 різними типами сприймання інформації: візуальні, аудіальні, кінестетичні, дискретні описано у праці [6]. Багато авторів відзначають, що використання Smart Boards допомагає дітям адаптуватися в суспільстві з різними видами сприйняття інформації та проблемами розвитку. Вони вважають, що багато із цих стилів навчання - навіть потреби слабозрячих, 3 порушенням слуху та інших студентів зі спеціальними потребами - можуть бути вирішені, коли проведення занять і навчальна діяльність включають використання інтерактивної дошки [6].

Підготовка до проведення заняття із застосуванням мультимедійних ресурсів вимагає від викладача елементарних знань роботи з комп'ютером і мультимедійною дошкою, затрат значної частини вільного часу і врахування специфіки підготовки майбутніх педагогів. Smart Board, зазначає С. Василенко, надає викладачам і студентам повноцінне інтерактивне навчальне середовище для обміну ідеями, інформацією, зображеннями, анімацією, аудіо або відео. Навчання набагато потужніше, якщо воно мультимодальне, a Smart Board підтримує декілька різних стилів навчання - візуальнопросторового, слухового та кінестетичного [7].

Технологія організації навчальної взаємодії викладача i студентів 3 використанням мультимедійної дошки передбачає побудову навчання на основі активної діяльності всіх іiі учасників; повагу до особистості дитини; організацію навчального співробітництва за нетрадиційною схемою (викладач - студенти мультимедійно-розвивальне середовище); створення інтерактивного освітнього середовища тощо.

Діяльність викладача і студентів за цією технологією можна розподілити на кілька етапів.

1. Етап стимулювання і мотивації навчально-пізнавальної діяльності студентів.

Реалізація цього етапу через упровадження мультимедійних засобів у навчальному процесі відбувається через вплив на різні органи відчуття суб'єктів навчання, що забезпечує швидке й доступне сприймання нової інформації.

Використання мультимедійної дошки на цьому етапі дозволяє прискорювати темп навчання, підвищувати активність студентів, організовувати навчання в яскравій динамічній формі. Можливості інструментів програми Smart Notebook дозволяють записувати будь-яку інформацію «електронним маркером» на поверхні екрану, супроводжувати матеріал лекції помітками і зауваженнями, акцентувати увагу на ключових поняттях теми, створювати флеш-анімації, робити кольором позначки i коментарі поверх вкладених відеокліпів, рисунків або створених презентацій [5, с. 251]. 
Але важливо розуміти, що ефективність роботи з дошкою багато в чому залежить від самого викладача і від того, як він застосовує різні її можливості.

2. Eтап актуалізації життєвого досвіду, вивчення нового матеріалу.

Цей етап реалізує викладач відповідно до визначених на початку заняття цілей, через зміну форм і видів традиційної діяльності. Педагог намагається створити такі умови взаємодії, які б психологічно мотивували в студентів потребу зробити «відкриття нового знання». Так, під час опрацювання теми «Методика вивчення величин у початковій школі» 3 використанням мультимедійної дошки для студентів спеціальності «Початкова освіта» спочатку актуалізуємо знання студентів щодо історичного розвитку поняття «величина», а потім вони на основі цих знань формулюють власне визначення і співвідносять його 3 представленим їм пізніше на дошці.
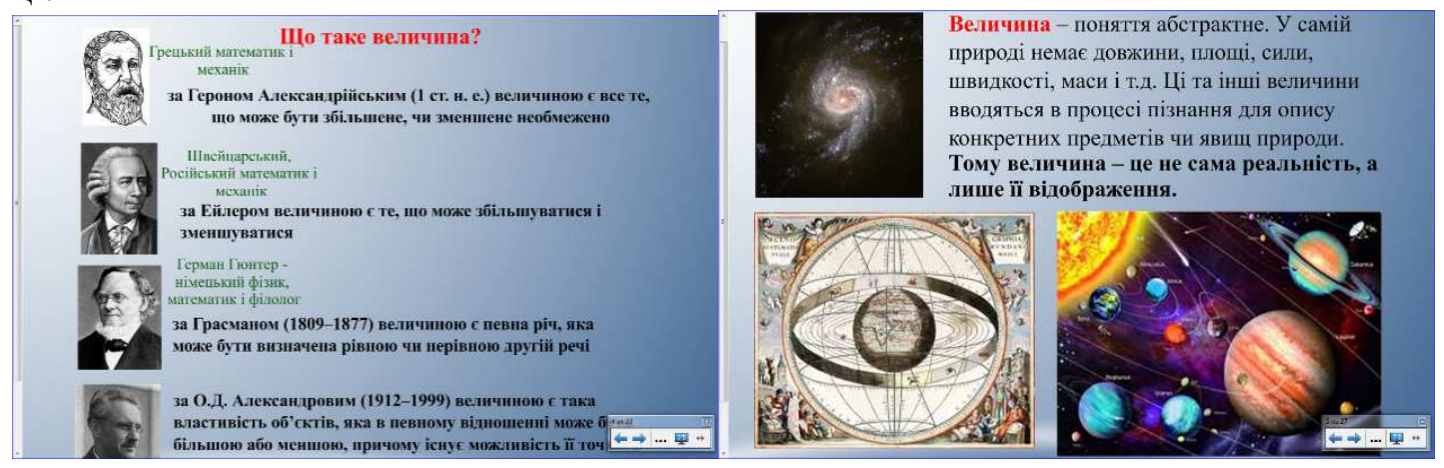

Pис. 1. Фрагмент навчального заняття в програмі Smart Notebook

3. На етапі формування вмінь, навичок та способів дій у традиційній технології викладач використовує інтерактивні методичні прийоми такі, як «акваріум», «ажурна пилка», робота в парах, у малих групах, навчальна дискусія, прийоми взаємонавчання, ділова гра та інші. У нашому випадку використовуємо інтерактивні можливості Smart Board. Пропонуємо студентам перелік властивостей величин 3 пропущеними ключовими словами. Вони обдумують, обговорюють у парах, а потім здійснюють перевірку, рухаючи «лакмуси» на екрані, які проявляють пропущені слова.

4. Узагальнювальний етап. Для діагностики рівня засвоєння навчального матеріалу можна використовувати колекцію інтерактивних засобів з пакету SMART Learning Suite нової версії Smart notebook 17.1.

Пакет програмного забезпечення SMART Learning Suite включає в себе: Smart Notebook, Smart Lab, Smart Response 2, Smart Amp, Smart Learning Suite Online.

Доступний у програмному забезпеченні Smart Response 2 - це інструмент оцінювання, що полегшує і пришвидшує створення наборів запитань. Нові інструменти для оцінювання 3 цього додатка допомагають викладачам оцінювати студентів для ефективного керування навчанням [8]. Студенти отримують доступ до інструменту оцінок, перейшовши на classlab.com на своїх мобільних пристроях.

Для роботи з додатком Smart Response 2 студентам необхідно встановити на свій смартфон, планшет чи ноутбук додаток SmartLab, зареєструватися у класі викладача (для цього потрібно ввести 8-значний код, який надає сам викладач), ввести своє прізвище та ім'я і почати проходження тесту. Викладач у своєму створеному занятті (класі) може бачити й аналізувати результати проходження тесту всіма учасниками інтерактивного навчального середовища (рис. 2). Такий сучасний і мобільний підхід до оцінювання якості знань студентів дозволяє проходити тестування в будь-який зручний для студентів час, працювати віддалено у класі викладача зі своїх пристроїв, швидко змінювати вид діяльності на занятті. 


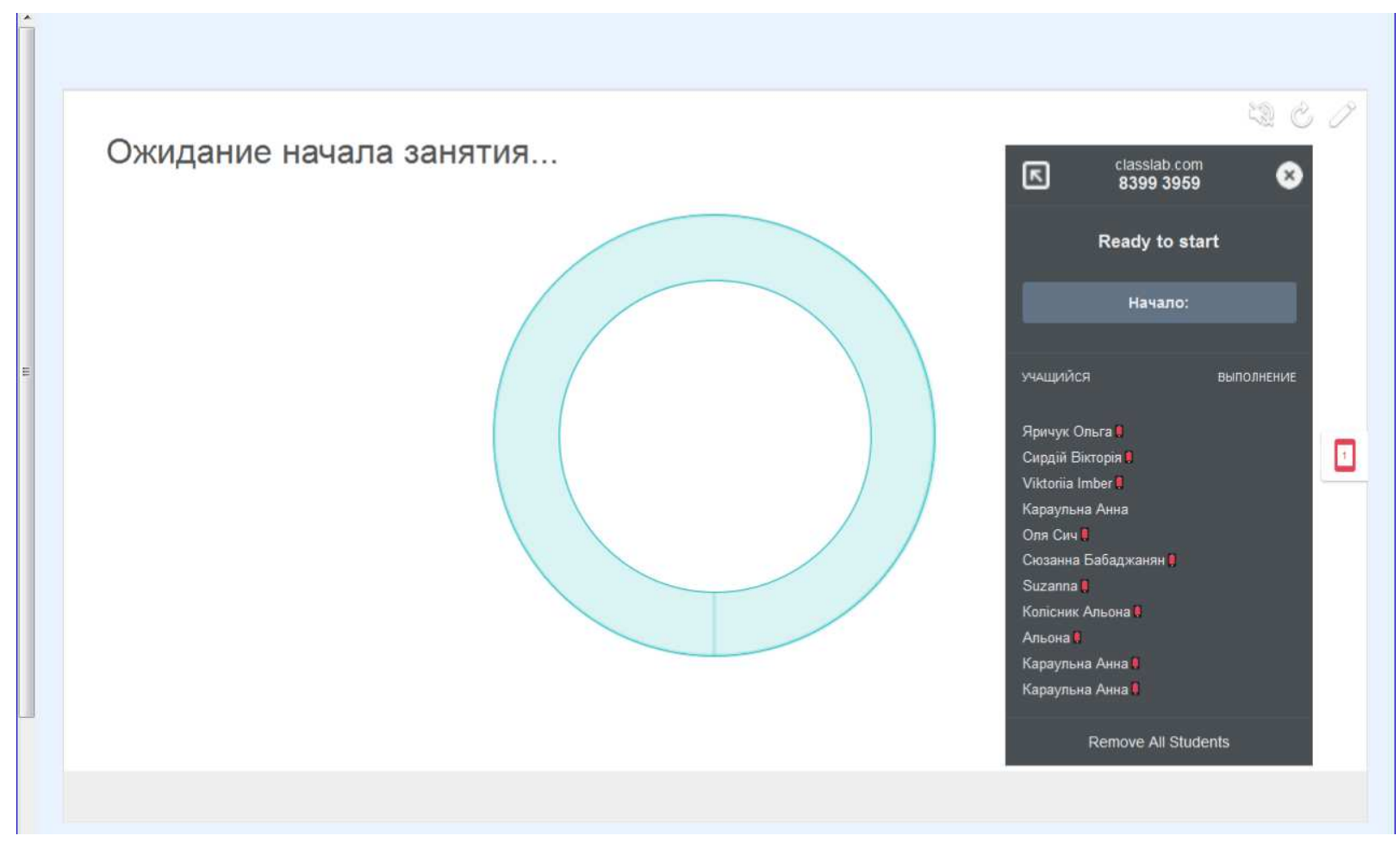

Pис. 2. Вигляд вікна Response 2 під час виконання студентами завдання в режимі оnline

Використання Smart Amp як хмарного сервісу, на платформі Google Cloud для роботи з мобільних пристроїв, дозволяє організовувати співпрацю студентів у межах спільного навчального середовища, а також підтримувати з ними зворотній зв'язок під час навчання. Додаток Smart Amp дозволяє переглядати файли на Google Диску та керувати ними, вивантажувати матеріали занять. 3 допомогою Smart Amp можна об’єднувати різні пристрої в єдиний віртуальний робочий простір.

3 вересня 2017 року став доступним новий розроблений компонент програмного забезпечення SMART Learning Suite Online, який є сучасним новим способом активізації навчання і залучення студентів до розв'язання поставлених завдань у режимі online. Завдяки цьому пакету програм студенти можуть працювати 3 темами на будь-яких персональних пристроях: на телефонах, планшетах і комп'ютерах. Вони виконують інтерактивні завдання і мають змогу навчатися у своєму власному темпі. Функції SMART Learning Suite Online включають такі можливості:

- доступ до матеріалів інтерактивного уроку Smart Notebook, в т. ч. Smart Lab, 3 будь-якого персонального пристрою;

- створення в браузері нових інтерактивних завдань у Smart Lab та інтерактивного опитування Smart Response2;

- доступ до щойно створених уроків Smart Notebook чи які були створені раніше;

- миттєвий доступ до створення активності «Викрик» (Shoutit Out!) під час уроку [9].

Smart Lab (Lesson Activity Builder) - додаток, за допомогою якого можна створювати низку інтерактивних завдань для студентів, учнів, дітей дошкільного віку. Розглянемо дидактичні функції додатка Smart Lab, які ми разом зі студентами використовуємо на заняттях $з$ методики навчання освітньої галузі «Математика» для створення власних методичних розробок до уроків (табл. 1). 


\section{Дидактичні функції додатка SmartLab}

\begin{tabular}{|c|c|c|}
\hline Інструменти Smart Lab & Функціональні можливості & $\begin{array}{c}\text { Освітні завдання, які } \\
\text { вирішують }\end{array}$ \\
\hline $\begin{array}{l}\text { Fill in the Blanks } \\
\text { Заповнити пропуски }\end{array}$ & $\begin{array}{l}\text { Учні перетягують слова або } \\
\text { числа в пропуски }\end{array}$ & $\begin{array}{l}\text { Навчають компонувати, } \\
\text { розвивають пам'ять }\end{array}$ \\
\hline $\begin{array}{l}\text { Flip out } \\
\text { Переворот }\end{array}$ & $\begin{array}{l}\text { Створені дидактичні картки, } \\
\text { які дозволяють вивчати } \\
\text { взаємно-однозначні } \\
\text { відповідності }\end{array}$ & $\begin{array}{l}\text { Розвивають пам'ять, } \\
\text { словниковий запас }\end{array}$ \\
\hline $\begin{array}{l}\text { Game Show } \\
\text { Iгрове шоу }\end{array}$ & $\begin{array}{l}\text { Учні по черзі відповідають } \\
\text { на запитання з декількома } \\
\text { варіантами відповідей } \\
\end{array}$ & $\begin{array}{l}\text { Стимулює швидкість } \\
\text { мислення, навчає працювати } \\
\text { командно }\end{array}$ \\
\hline $\begin{array}{l}\text { Label Reveal } \\
\text { Відкривання підписів }\end{array}$ & $\begin{array}{l}\text { Учні відкривають і вивчають } \\
\text { підписи певних частин } \\
\text { зображення } \\
\end{array}$ & $\begin{array}{l}\text { Розвиває дедуктивне } \\
\text { мислення, пам'ять }\end{array}$ \\
\hline $\begin{array}{l}\text { Match ‘em Up! } \\
\text { Відповідності }\end{array}$ & $\begin{array}{l}\text { Завдання на встановлення } \\
\text { взаємно-однозначної } \\
\text { відповідності }\end{array}$ & Розвиває пам'ять \\
\hline $\begin{array}{l}\text { Monster Quiz } \\
\text { Тест } 3 \text { монстрами }\end{array}$ & $\begin{array}{l}\text { Тест з декількома варіантами } \\
\text { відповідей і питаннями типу } \\
\text { «true/false» }\end{array}$ & Навчає командної роботи \\
\hline $\begin{array}{l}\text { Rank order } \\
\text { Порядок сортування }\end{array}$ & $\begin{array}{l}\text { Учні систематизують } \\
\text { елементи, об'єкти у } \\
\text { необхідному порядку }\end{array}$ & $\begin{array}{l}\text { Навчає систематизувати, } \\
\text { порівнювати, } \\
\text { упорядковувати }\end{array}$ \\
\hline $\begin{array}{l}\text { Response } 2 \\
\text { Опитування }\end{array}$ & $\begin{array}{l}\text { Зрозумілий і спрощений } \\
\text { інструмент оцінювання, що } \\
\text { полегшує і пришвидшує } \\
\text { створення наборів запитань } \\
\text { (альтернативні запитання, } 3 \\
\text { короткою відповіддю, } \\
\text { запитання типу «true/false») }\end{array}$ & $\begin{array}{l}\text { Навчає працювати } \\
\text { індивідуально, здійснювати } \\
\text { самоконтроль, допомагає } \\
\text { викладачам оцінювати } \\
\text { студентів для ефективного } \\
\text { керування навчанням }\end{array}$ \\
\hline $\begin{array}{l}\text { Shout it out! } \\
\text { Викрикуй! }\end{array}$ & $\begin{array}{l}\text { Учні використовують свої } \\
\text { пристрої для вивантаження } \\
\text { текстів, зображень }\end{array}$ & $\begin{array}{l}\text { Навчає генерувати ідеї, } \\
\text { реалізовує технологію } \\
\text { мозкового штурму }\end{array}$ \\
\hline $\begin{array}{l}\text { Speedup } \\
\text { Гонки }\end{array}$ & $\begin{array}{l}\text { Тест на швидкість } 3 \\
\text { декількома варіантами } \\
\text { відповідей і запитаннями } \\
\text { типу «true/false» }\end{array}$ & $\begin{array}{l}\text { Стимулює швидкість } \\
\text { мислення, підтримує } \\
\text { прагнення до змагання }\end{array}$ \\
\hline $\begin{array}{l}\text { Super Sort } \\
\text { Суперсортування }\end{array}$ & $\begin{array}{l}\text { Сортування елементів на дві } \\
\text { категорії }\end{array}$ & $\begin{array}{l}\text { Навчає групувати, } \\
\text { класифікувати об'єкти за } \\
\text { певною ознакою }\end{array}$ \\
\hline
\end{tabular}

Усі інтерактивні завдання дозволяють викладачеві створювати власний методичний супровід лекції, практичного заняття, наповнювати змістом, використовувати нові форми роботи й нові інструменти оцінюванням навчальних досягнень студентів. Усе це допомагає робити навчальну взаємодію на занятті невимушеною, творчою, стимулює студентів до співпраці, інтерактивної взаємодії, до упровадження нових форм роботи у власній педагогічній діяльності. 


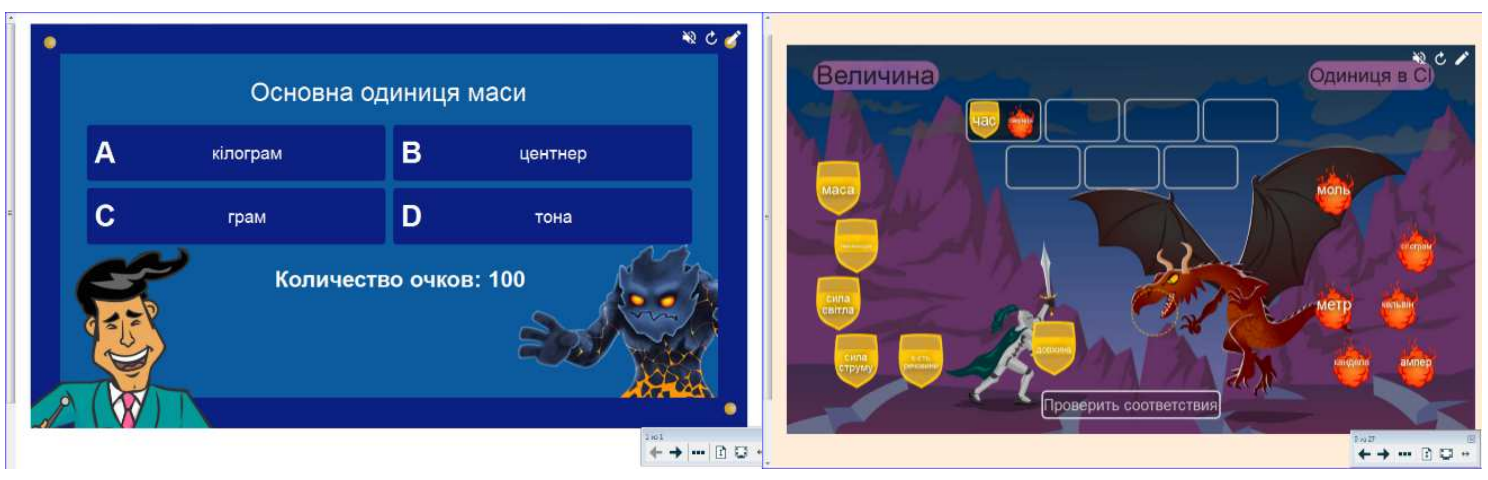

Pис. 3. Приклади використання інтерактивних додатків Game Show ma Match 'em Up

Набуті студентами уміння створювати інтерактивні завдання допомагають їм бути мобільними, обізнаними 3 новими можливостями сучасних технологій, готовими до викликів інформаційного суспільства, швидко реагувати на потреби нової української школи.

\section{3. ВИСНОВКИ ТА ПЕСПЕКТИВИ ПОДАЛЬШИХ ДОСЛІДЖЕНЬ}

Отже, підсумовуючи вищезазначене, можна $з$ упевненістю констатувати, що Smart Board відіграє значну роль в організації навчальної взаємодії викладача i студентів, забезпечує інтерактивний спосіб проведення занять, залучаючи аудіальний, візуальний i кінестетичний канали сприйняття інформації, сприяє підвищенню пізнавальної активності студентів та їхньої інформаційної компетентності як необхідної складової професійної компетентності в сучасному інформаційному суспільстві, надає майбутнім педагогам можливості для креативної реалізації методичних новацій.

Запропоновані автором етапи організації навчальної взаємодії викладача i студентів, а також форми залучення студентів до розв'язання поставлених завдань у режимі online засобами Smart Board створюють ефективний вплив на активізацію навчання у вищому навчальному закладі й можуть бути успішно реалізовані у сучасній системі освіти. Це забезпечить можливість для викладачів створювати інтерактивні заняття, вивільняти час для оцінки навчальних досягнень студентів, опановувати нові форми організації занять у режимі online, забезпечувати навчання студентів у їхньому власному темпі.

Перспективи подальших наукових досліджень вбачаємо у більш детальному розгляді можливостей використання таких додатків, як Smart Amp, SMART Learning Suite Online для організації кооперативного навчання студентів у межах спільного навчального середовища, а також залучення їх до розв'язання поставлених завдань у режимі online.

\section{СПИСОК ВИКОРИСТАНИХ ДЖЕРЕЛ}

[1] В. В. Осадчий, К. П. Осадча, І. М. Сердюк, Використання мультимедійного проектора та електронно інтерактивної дошки в навчально-виховному прочесі ВНЗ. Мелітополь, Україна : ТОВ “Видавничий будинок ММД”, 2010.

[2] О. П. Буйницька, Інформаційні технології та технічні засоби навчання. Київ, Україна: Центр учбової літератури, 2012.

[3] Т. І. Носенко Інформаційні технології навчання. Київ, Україна: Київ. ун-т ім. Бориса Грінченка, 2011. 
[4] Ю. Ю. Мельничук, "Використання інтерактивної дошки під час викладання філологічних дисциплін у виші”, Наукові записки Рівненського державного гуманітарного університету. Оновленн язмісту, форм та методів навчання і виховання в закладах освіти, Вип.15, с. 179-182, 2017.

[5] В. І. Імбер, “Упровадження мультимедійних технологій у підготовку майбутніх вихователів дошкільних навчальних закладів”, Педагогічні науки: теорія, історія, інноваційні технології, №5(49), c. 247-255, 2015.

[6] S. Martin, E. Shaw, L. Daughenbaugh,"Using smart boards and manipulatives in the elementary science classroom", Techtrends: linking research \& practice to improve learning, 58(3), pp. 90-96, 2014.

[7] S. Vasylenko, Experience using multimedia boards for visualization, conducting pedagogical discussions, developing interactive exercises for primary school, Open educational e-environment of modern University, № 3, pp. 173-185, 2017.

[8] Creating lesson activities and using SMART Lab by using Response 2 [Електронний ресурс]. Доступно:https://support.smarttech.com/docs/software/notebook/notebook-17/en/using/creating-lessonactivities/using-response-2.cshtml.

[9] Smart Learning Web Service [Електронний ресурс]. Доступно: https://education.smarttech.com/en/products/smart-learning-suite/online.

Матеріал надійшов до редакиіï 22.11.2017p.

\title{
ОРГАНИЗАЦИЯ УЧЕБНОГО ВЗАИМОДЕЙСТВИЯ ПРЕПОДАВАТЕЛЯ И СTУДЕНТОВ СРЕДСТВАМИ SMART BOARD
}

\author{
Имбер Виктория Ивановна \\ кандидат педагогических наук, старший преподаватель \\ Винницкий государственный педагогический университет имени Михаила Коцюбинского, \\ г. Винница, Украина \\ ORCIDID0000-0003-2908-9654 \\ imbervika@gmail.com
}

\begin{abstract}
Аннотация. В статье рассматриваются этапы организации учебного взаимодействия преподавателя и студентов средствами Smart Board. Описаны возможности обновленного пакета программного обеспечения SMART Learning Suite, в частности интерактивное приложение Smart Lab для организации обучения по игровым технологиям, новый инструмент оценивания знаний студентов Smart Response 2, организацию сотрудничества студентов в общем виртуальном рабочем пространстве Smart Amp, работу студентов на любых персональных устройствах, выполнение заданий в режиме online, используя SMART Learning Suite Online. Определено, что новые формы организации учебного взаимодействия преподавателя и студентов могут быть успешно реализованные в современной системе образования. Это обеспечит возможность для преподавателей создавать интерактивные занятия, высвобождать время для оценки учебных достижений студентов, осваивать новые формы организации занятий в режиме online, обеспечивать обучение студентов в их собственном темпе. Приведены примеры интерактивных упражнений и способы организации учебной деятельности студентов с использованием инструментов Smart Lab.
\end{abstract}

Ключевые слова: учебное взаимодействие преподавателя и студентов; интерактивная доска; виртуальное рабочее пространство; пакет SMART Learning Suite.

\section{EDUCATIONAL COOPERATIVE LEARNING BETWEEN THE TEACHER AND THE STUDENTS USING SMART BOARD TOOLS}

\author{
Viktoriia I. Imber \\ $\mathrm{PhD}$ (in Pedagogical Sciences), Senior Lecturer \\ Vinnytsia State Pedagogical University named after MikhailoKotsyubynskyi, Vinnytsia, Ukraine \\ ORCID ID 0000-0003-2908-9654 \\ imbervika@gmail.com
}




\begin{abstract}
The article deals with the stages in the organization of teacher -student educational interaction by means of Smart Board. The possibilities of the updated SMART Learning Suite software have been described, including the Smart Lab interactive application for game technology learning, the new Smart Response 2 used as a student's assessment tool for the organization of students' cooperation within the single virtual Smart Amp workspace, student's personal devices usage, online assignments accomplishment through Smart Learning Suite Online. It has been determined that the new forms of teacher-student educational interaction can be successfully implemented in the modern educational system. This will provide an opportunity for teachers to create interactive lessons, to find free time for assessing students' achievements, master new forms of online classroom training, and provide the students' training at their own pace. The set of interactive exercises and how to organize student's learning process with the use of SmartLab tools have been introduced.
\end{abstract}

Keywords: teacher-student interaction; Smart Board; virtual working space; Smart Learning Suite.

\title{
REFERENCES (TRANSLATED AND TRANSLITERATED)
}

[1] V.V.Osadchyi, K.P.Osadcha, I.M. Serdyuk,Using a multimedia projector and a Smart Board in the educational process of higher educational institutions. Melitopol, Ukraine: LLC Publishing House MMD, 2010 (in Ukrainian).

[2] O. P. Buynytska, Informative technologies and technical means of training, Kyiv, Ukraine: Educational Literature Center, 2012 (in Ukrainian).

[3] T. I. Nosenko, Informative technologies of learning, Kyiv, Ukraine: Borys Hrinchenko University of Kyiv, 2011 (in Ukrainian).

[4] Yu. YuMelnychuk, "Using a Smart Board in teaching philological disciplines in higher educational establishment", Scientific Notes of Rivne State Humanitarian University. Updating content, forms and methods of teaching in educational institutions, Issue 15, p. 179-182, 2017 (in Ukrainian).

[5] V. I. Imber, "Implementation of multimedia technologies in the future pre-school teachers' training", Pedagogical sciences: theory, history, innovative technologies, № 5 (49), p. 247-255, 2015 (in Ukrainian).

[6] S.Martin, E. Shaw, L.Daughenbaugh,"Using smart boards and manipulatives in the elementary science classroom",Techtrends: linking research \& practice to improve learning, 58(3), pp. 90-96, 2014 (in English).

[7] S. Vasylenko, Experience using multimedia boards for visualization, conducting pedagogical discussions, developing interactive exercises for primary school,Open educational e-environment of modern University, № 3, pp. 173-185, 2017 (in English).

[8] Creating lesson activities and using SMART Lab by using Response 2[Online]. Available:https:/support.smarttech.com/docs/software/notebook/notebook-17/en/using/creating-lessonactivities/using-response-2.cshtml.(in English).

[9] Smart Learning Web Service [Online].Available:https://education.smarttech.com/en/products/smartlearning-suite/online(in English).

\section{$(\mathrm{Cc}) \mathrm{BY}$-NC-SA}

This work is licensed under Creative Commons Attribution-NonCommercial-ShareAlike 4.0 International License. 